\title{
Vegetation cover change detection and assessment in arid environment using multi-temporal remote sensing images and ecosystem management approach
}

\author{
Anwar Abdelrahman Aly ${ }^{1,3}$, Abdulrasoul Mosa Al-Omran ${ }^{1}$, Abdulazeam Shahwan Sallam ${ }^{1}$, \\ Mohammad Ibrahim Al-Wabel ${ }^{1}$, and Mohammad Shayaa Al-Shayaa ${ }^{2}$ \\ ${ }^{1}$ Soil Science Dept., King Saud University, Riyadh, Saudi Arabia \\ ${ }^{2}$ Agricultural Extension and Rural Community Dept., King Saud University, Riyadh, Saudi Arabia \\ ${ }^{3}$ Soil and Water Science Dept., Faculty of Agric., Alexandria University, Alexandria, Egypt
}

Correspondence to: Abdulrasoul Mosa Al-Omran (rasoul@ksu.edu.sa, anwarsiwa@yahoo.com)

Received: 21 February 2016 - Published in Solid Earth Discuss.: 25 February 2016

Revised: 20 April 2016 - Accepted: 21 April 2016 - Published: 29 April 2016

\begin{abstract}
Vegetation cover (VC) change detection is essential for a better understanding of the interactions and interrelationships between humans and their ecosystem. Remote sensing (RS) technology is one of the most beneficial tools to study spatial and temporal changes of VC. A case study has been conducted in the agro-ecosystem (AE) of Al-Kharj, in the center of Saudi Arabia. Characteristics and dynamics of total VC changes during a period of 26 years (1987-2013) were investigated. A multi-temporal set of images was processed using Landsat images from Landsat4 TM 1987, Landsat7 ETM+2000, and Landsat8 to investigate the drivers responsible for the total VC pattern and changes, which are linked to both natural and social processes. The analyses of the three satellite images concluded that the surface area of the total VC increased by $107.4 \%$ between 1987 and 2000 and decreased by $27.5 \%$ between years 2000 and 2013. The field study, review of secondary data, and community problem diagnosis using the participatory rural appraisal (PRA) method suggested that the drivers for this change are the deterioration and salinization of both soil and water resources. Ground truth data indicated that the deteriorated soils in the eastern part of the Al-Kharj AE are frequently subjected to sand dune encroachment, while the southwestern part is frequently subjected to soil and groundwater salinization. The groundwater in the western part of the ecosystem is highly saline, with a salinity $\geq 6 \mathrm{dS} \mathrm{m}^{-1}$. The ecosystem management approach applied in this study can be used to alike $\mathrm{AE}$ worldwide.
\end{abstract}

\section{Introduction}

Many researchers working in ecosystem management (EM) find it necessary to integrate communities as part of an ecosystem rather than treating them as a separate entity (Aly, 2007; Reed et al., 2009). The ecosystems give humankind many services such as provisioning services (i.e., food, water, timber, fiber, and genetic resources), regulating services (i.e., the regulation of climate, floods, disease, and water quality), cultural services (i.e., recreational, aesthetic, and spiritual benefits), and supporting services (i.e., soil formation, pollination, and nutrient cycling) (Aly, 2007; Bochet, 2015). Soil and vegetation as a part of ecosystems also give many services to the humankind and play an important role in the earth system. The soil can act as a filter of heavy metals and parasitic microorganisms; consequently, prevent plant and groundwater from contamination (Brevik et al., 2015; Keesstra et al., 2012). Implementing sustainable EM implies improving the quality of community life without depleting the ecosystems for future generations. Brodt et al. (2011) and Maltby (2000) said that the newer concept of sustainability includes three dimensions, defined by three broad goals: economic opportunity, social equity, and environmental health. When these goals are reached, the sustainability will be achieved. However, Richardson et al. (2010) concluded that severe degraded ecosystem may shift the EM goals from ecosystem restoration and sustainability to reconstructing entirely new ecosystem. Since the late 1980s an integration between EM, RS, GIS, and GPS has received sub- 
stantial consideration in the literature (Ehlers et al., 1989; Hinto, 1996; Trabaquini et al., 2012). This integration helps us tackle more research problems related to EM. Nevertheless, the approaches by which these techniques are integrated have become more complicated due to the diversification of the fields that are required to be integrated (Gao, 2002). Indeed the RS, GIS, and GPS provide desired technologies for land and environmental management (Leh et al., 2015; Seelan et al., 2003; Zucca et al., 2015). Two terms are usually used in abundance by land management researchers: land cover (LC) and land use (LU). The LC is defined as a physical material-covered earth surface; LU is the human activities or economic functions related to specific part of land (Singh, 2013). The LC comprises vegetation, asphalt, bare ground, rivers, lakes, etc., whilst the vegetation cover (VC) includes only planted land, i.e., grass, trees (Aly, 2007; Singh, 2013). Loss of VC and plant species diversity reduces resistance of soil erosion and soil fertility (Berendse et al., 2015; Cerdà and Doerr, 2005; Yu and Jia, 2014). The VC improves the infiltration rate and decreases surface runoff and erosion (Cerdà, 1999). Furthermore, the VC has considerably affected the global warming process through emissions of $\mathrm{CO}_{2}$. However, $\mathrm{C}$ sequestration by afforestation in terrestrial ecosystems could contribute to the decrease of atmospheric $\mathrm{CO}_{2}$ rates (Muñoz-Rojas et al., 2015). The analysis of the impact of LU changes on landscape processes can aid the future policies of the agro-ecosystem (AE) (Debolini et al., 2015). The RS technology is usually used in EM (Almeida et al., 2005; Croft et al., 2012; Gong et al., 2015; Mohawesh et al., 2015; Rawat, 2013; Xie, 2008). Vrieling (2006) concluded that four types of factors are included by remote sensing (RS): topography, soil properties, $\mathrm{VC}$, and management practices. Aly (2007) used the RS technology in the holistic approach of AE sustainable management in Siwa, located in Egypt. Furthermore, Setiawan and Yoshino (2012) compared series of images through time to derive the land changes in Tsukuba, Japan. Often remote sensing imagery is imported into GIS software to facilitate analysis (Fichera et al., 2012). Chowdary et al. (2001) used the Indian remote sensing satellite data of 1988 and 1996 to monitor the land resources and evaluate the land cover changes through a comparison of images acquired for same area at different times. Yang et al. (1999) analyzed different temporal images of Landsat MSS (1978 and 1981) and TM (1988, 1992, and 1996) for the purpose of detecting the coastal line change of Yellow River Delta. Suliman (2001) acquired three differently dated satellite Thematic Mapper (TM) images for 1984, 1993, and 1999, in addition to topographic maps, to obtain a new vulnerability map that can detect erosion, reclamation, and development of Rosetta and Mutubas districts (in Arabic, markazes). El-Bana (2003) used two differently dated satellite TM images to obtain quantified changes in LU in the northwestern part of Kafr el-Sheikh Governorate, Egypt. Furthermore, Aly (2007) used three satellite images from 1973 (MSS), 2000 (ETM), and 2005 (ASTER) to detect changes of LC in Siwa oasis, Egypt. Desprats et al. (2014) used satellite remote sensing to identify VC in the western part of the Kingdom of Saudi Arabia (KSA). The use of RS and field studies in the KSA can be summarized: sand dunes and soil and groundwater deterioration are considered the main problems that threaten the AEs (Algahtani et al., 2015; Aly et al., 2015a; Alyemeni, 2000). The sand dunes cover more than quarter of KSA surface (Alyemeni, 2000). These include four major sandy deserts (Nafud, Dahna, Rub' al Khali, and Juffarah) in addition to other locally scattered sandy areas (Alyemeni, 2000). AEs are rarely found in the vast dryland of KSA; furthermore, found AEs were usually considered fragile (Al-Omran et al., 2014). Al-Kharj is a productive AE set in a desert depression in central KSA and is irrigated by waters originating from natural springs and dug wells with lush date palms, other fruits (e.g., grapes), and vegetables (e.g., lettuce, carrots, tomatoes, cucumbers, and melons). It is a fragile dryland AE that has a low degree of resilience to external stresses and has a low carrying capacity (Al-Omran et al., 2014). Some primary studies recorded that the soils and groundwater in Al-Kharj were deteriorating in an alarming way to lower suitability classes and sometimes becoming unsuitable for cultivation (Al-Harbi, 2005). Consequently, the main objectives of this study are (i) to define the Al-Kharj, Saudi Arabia, AE problems and sustainability using community diagnosis and field study; (ii) to detect the Al-Kharj's VC changes using RS; and (iii) to develop interventions that help restore the ecosystem's functions and integrity and thus enhance the community's livelihood and promote social equity.

\section{Materials and methods}

\subsection{Study area}

The Al-Kharj is a fragile dryland AE that has low resilience and carrying capacity. The ecosystem is located in arid conditions in the middle of the Kingdom of Saudi Arabia, east of Riyadh city. It is located at $24^{\circ} 8^{\prime} 54^{\prime \prime} \mathrm{N}, 47^{\circ} 18^{\prime} 18^{\prime \prime} \mathrm{E}$ (Fig. 1). The groundwaters are considered the main source of irrigation, and the $\mathrm{AE}$ grows various fruits and vegetables (e.g., date palms and grapes, tomatoes, cucumbers, melons) (AlOmran et al., 2013). The Al-Kharj is located at $1360 \mathrm{~m}$ above sea level and its area is about $20000 \mathrm{~km}^{2}$ with a population of more than 600000 people. There are only two large towns in the studied AE (Dilam and Asseeh, with populations of 8492 and 49856 people, respectively); however, there are three small towns (Al-Hayathim, Al-Yamamah, and Sulamiyya). Furthermore, the AE includes many small hamlets and villages (Hagras et al., 2013). The Wadi (valleys) of Al-Kharj is discharged by water from Wadi Hanifa and some other small wadis to compensate for part of the consumed groundwater. $\mathrm{Al}$-Kharj has included numerous springs since ancient times; consequently, it is considered richest ecosystem in water re- 


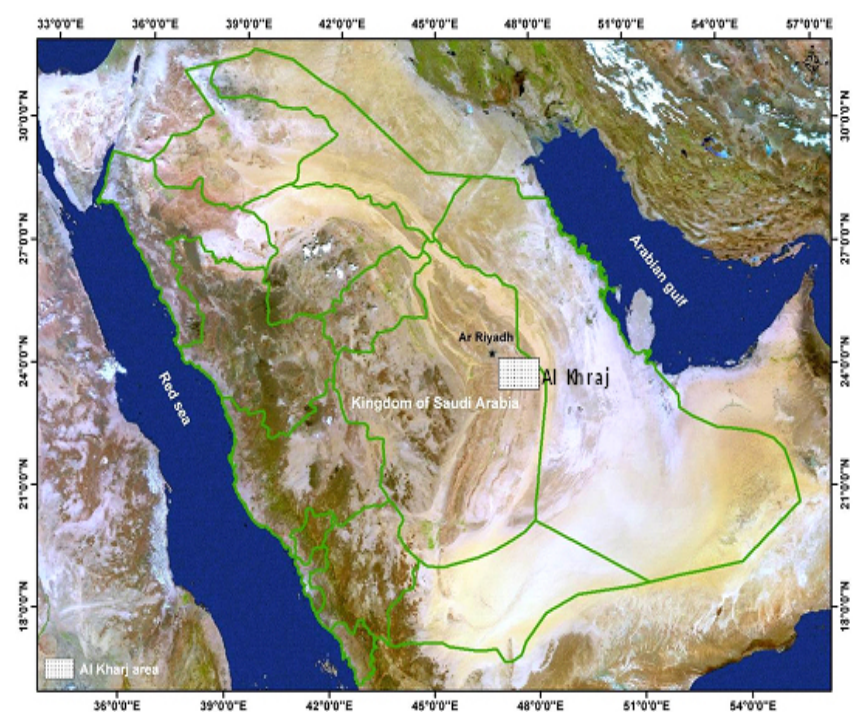

Figure 1. Location of the study area.

sources in the KSA. The studied AE has supported the KSA with grain, dairy products, and other produced crops and livestock products. Recently, the springs of Al-Kharj have dried up dramatically, like those in other places of the kingdom, due to recurring drought (McLaren, 2008).

\subsection{Ecosystem problem identification (community)}

The purpose of this part of the fieldwork is to identify the human activities and practices of the region, particularly those that enhance ecosystem degradation within socioeconomic and cultural constructs (Swallow et al., 2009). The knowledge, attitude, and practices (KAP) study was conducted using the participatory rural appraisal (PRA) method, which includes the review of earlier studies, field observations, substantial indicators, community townhall meetings, a sequence of one-on-one meetings, and buildup questionnaires. The PRA approach was used in this study to undertake a diagnosis of the community and the issues of land productivity, as well as their importance, as distinguished by the ecosystem community in order to interpret the changes found by RS (Mushove and Vogel, 2005; Shepherd, 2008). The PRA is a concentrated, regular but semi-structured learning practice conducted in a studied community by multidisciplinary teamwork with complete contribution of the ecosystem community and stakeholders (Chambers, 1994; Mikkelson, 1994). The PRA helps the researcher and community identify specific ecosystem problems and suggest solutions. The townhall meeting was held in Al-Kharj and included around 250 stakeholders and farmers. The questionnaire was field-tested, and modifications were made based on the results. The most suitable format appears to be an easy-torespond, non-time-consuming "tick box" structure. To this end, 123 suitable questionnaires were designed collectively by the research team in consultation with the local community to gather field information (Aly, 2007; Reed et al., 2009). Coding for different variables has been accomplished, information gathered through the 123 administered questionnaires has been statistically analyzed, and the tasks accomplished are recorded in this study.

\subsection{Remote sensing image characterization}

RS by satellite images has been used since 1972 by the first satellite, Landsat1 (Dagci and Kusek, 2008). Due to the vast study area, the proposed methodology is based on the use of remote sensing data. The very low cloud coverage on the Arabian Peninsula allows the acquisition of global imaging coverage of the study area over several years. In this study, a multi-temporal set of RS data of the Al-Kharj AE has been used to investigate vegetation cover changes (Fichera et al., 2012; Yuan et al., 2005; Lucas, 2007). The main part that can be distinguished by satellite image is the irrigated crops (Fig. 2). Three satellite images over a period of 26 years were acquired as follows.

1. Landsat4 TM: acquisition date is 27 November 1987, with seven spectral bands including thermal band. The ground sampling interval (pixel size) is $30 \mathrm{~m}$ reflective and $120 \mathrm{~m}$ thermal, and the scene size is $170 \mathrm{~km}^{2} \times 185 \mathrm{~km}^{2}$ (Fig. 2a).

2. Landsat7 ETM+: acquisition date is 16 December 2000, with eight spectral bands; the panchromatic band is $15 \mathrm{~m}$ resolution, thermal is $60 \mathrm{~m}$, and other reflective bands are $30 \mathrm{~m}$ (Fig. 2b).

3. Landsat8: acquisition date is 28 December 2013, with 11 spectral bands:

(a) multispectral bands $1-7$ and 9 at $30 \mathrm{~m}$

(b) panchromatic band 8 at $15 \mathrm{~m}$

(c) TIRS bands 10-11, resampled to $30 \mathrm{~m}$ (Fig. 2c).

In order to mitigate the seasonal effects, which often lead to errors in change detection, the study used only imagery acquired during the winter season, avoiding the uncertainness of interannual variability (Fichera et al., 2012).

\subsection{Delineation of vegetation cover changes}

In satellite images processing techniques, band ratio usually represents special surface characteristics. The difference of between bands is called the "index". If this index comes from near infrared (NIR) to red regions of spectral, it represents the vegetation index (VI). The green plants have chlorophyll and reflect infrared bands at high levels; consequently, it appears in red color in the satellite images (GeoMart, 2011).

For the normalization of the VI data, the vegetation index has been divided by the total of the two bands. The result is then called the normalized difference vegetation index 

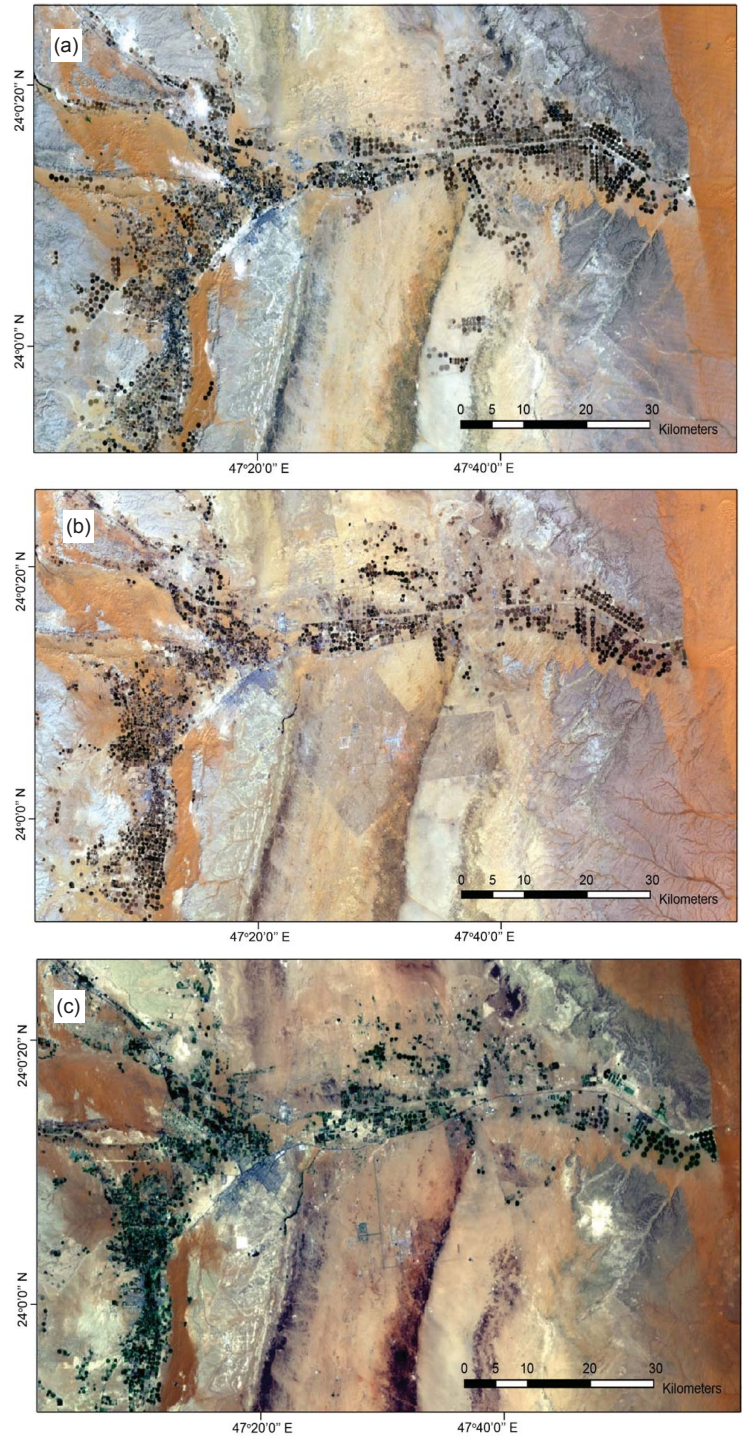

Figure 2. Satellite images of Al-Kharj ecosystem: (a) Landsat4 TM; (b) Landsat7 ETM+; (c) Landsat8.

(NDVI) and can be calculated as follows:

$\mathrm{NDVI}=(\mathrm{NIR}-\mathrm{red}) /(\mathrm{NIR}+\mathrm{red})$.

The NDVI takes 32 bit data varying between (-1) and (1). The positive values represent the vegetation, and the negative values represent the non-vegetated areas. These data can be scaled into eight varying bit values ( 0 to 255$)$, where $(-1)$ value goes to $(0)$ and $(+1)$ value goes to $(255)$. As a result of NDVI value, the light areas represent regions of high vegetation, and the dark areas represent regions of low vegetation (Fig. 3a, b). The NDVI images could be classified into three classes, namely dense vegetation cover (NDVI >0.5), moderate vegetation cover (NDVI $0.25-0.5$ ), and sparse vegetation cover (NDVI < 0.25), as shown in Fig. 4.
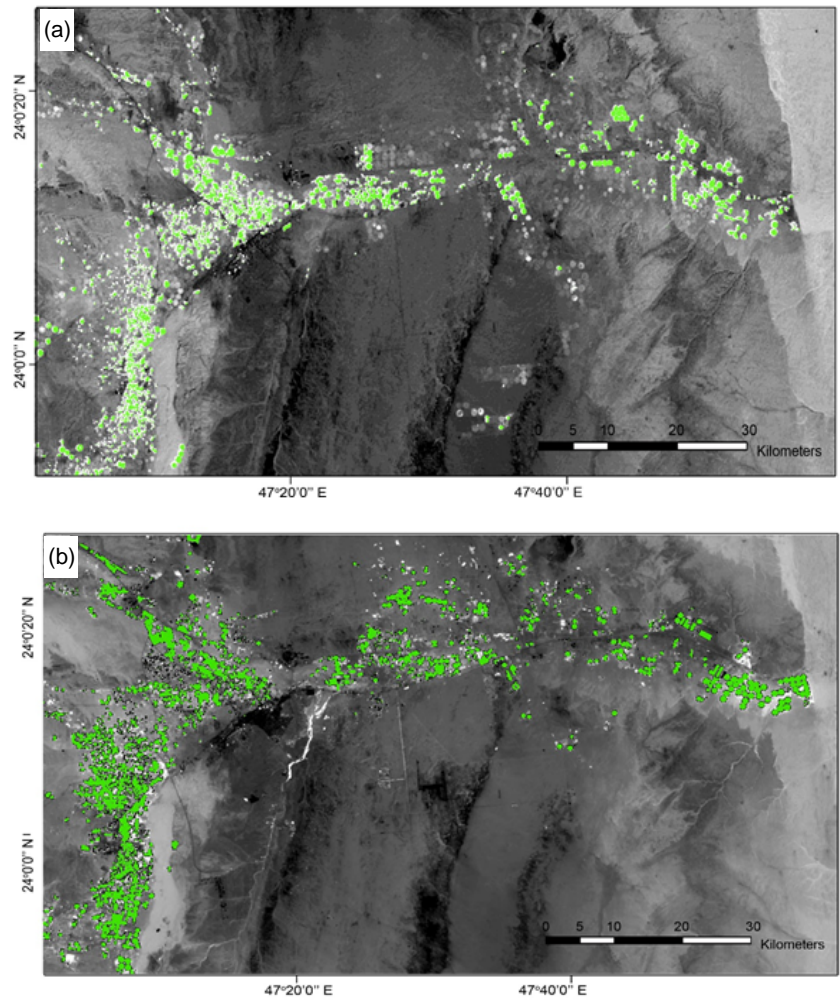

Figure 3. NDVI classification for Landsat satellite images of AlKharj from (a) 1987 and (b) 2013.

\subsection{Field study}

\section{Water and soil sampling and analysis}

180 groundwater samples were gathered from different locations in the Al-Kharj AE to cover the spatial variations of the ecosystem groundwater salinity (Fig. 5). All samples were analyzed for salinity using an electrical conductivity (EC) meter $\left(\mathrm{dS} \times \mathrm{m}^{-1}\right)$ (test kit model 1500_20, Cole and Parmer) at $25^{\circ} \mathrm{C}$. The groundwater soluble calcium, magnesium, sodium, potassium, chloride, and sulfate were determined using an ion chromatography system (ICS 5000, Thermo, USA); however, the bicarbonate and carbonate concentration were determined by titration with sulfuric acid $\left(\mathrm{H}_{2} \mathrm{SO}_{4}\right)$ (Matiti, 2004). Furthermore, 50 soil samples were collected from the studied area including deteriorated sites observed by satellite images for the year 2013 (ground truth). A soil paste extract was prepared, and the $\mathrm{EC}_{\mathrm{e}}$ was measured for each sample (Klute, 1986). In addition, 5TE (Decagon devices) soil moisture, EC, and temperature sensors were installed at three date palm fields in the Al Kharj AE. The first field (a) is located in the eastern part of the study area with no change of $\mathrm{VC}$ and used fresh water for irrigation $\left(\mathrm{EC}_{\mathrm{w}}=1.1 \mathrm{dS} \mathrm{m}^{-1}\right)$. The second (b) is a deteriorated field located in the middle to the western part and used saline brackish water for irrigation $\left(\mathrm{EC}_{\mathrm{w}}=6.5 \mathrm{dS} \mathrm{m}^{-1}\right)$. The third 

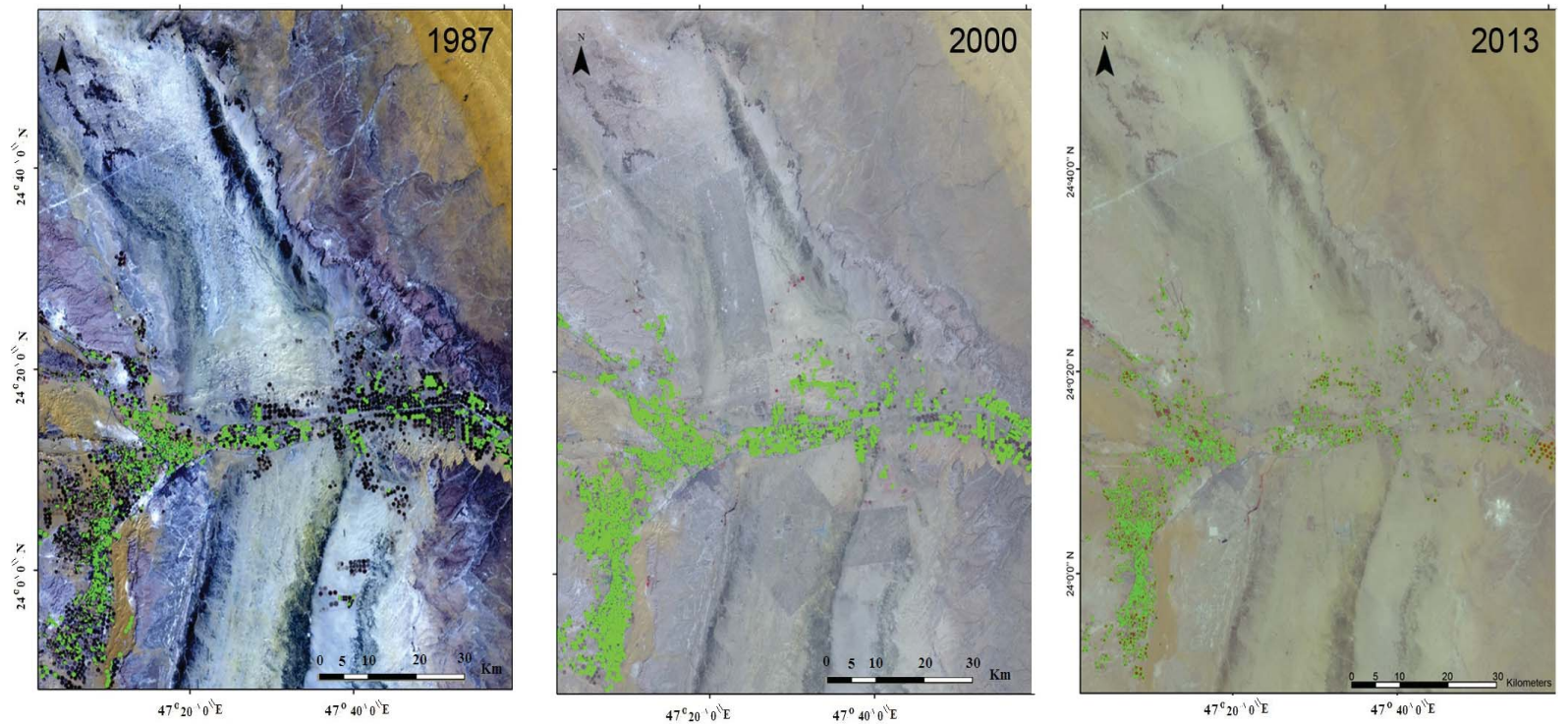

Figure 4. Vector layer for classified NDVI over Landsat satellite images from 1987, 2000, and 2013 (green is the cultivated area).

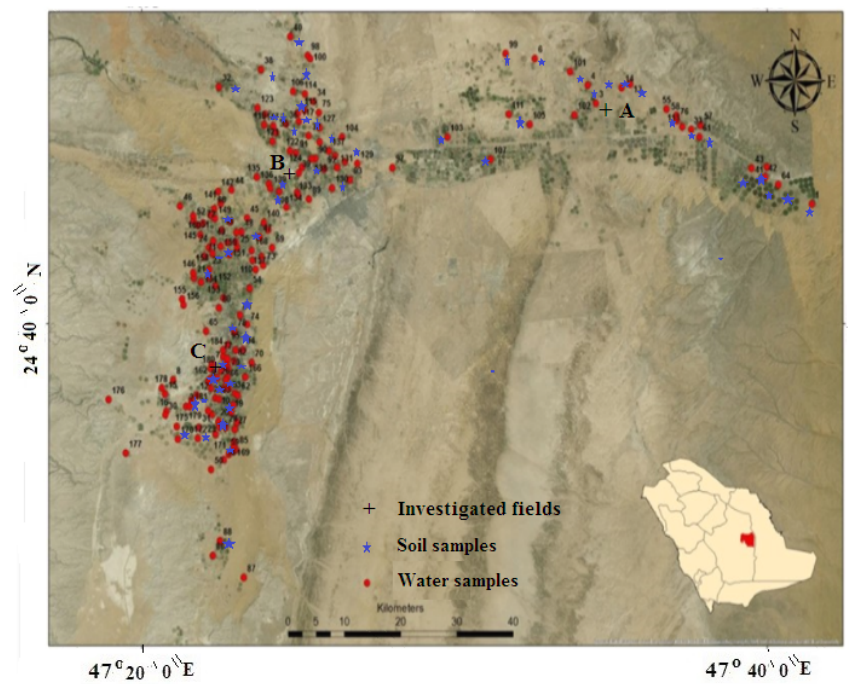

Figure 5. Location of the studied wells, soil samples, and investigated fields.

(c) is an abandoned field located in the southern part of the study area with notable decrease of VC; this field has no irrigation activities due to the high salinity of groundwater $\left(\mathrm{EC}_{\mathrm{w}}=10.2 \mathrm{dS} \mathrm{m}^{-1}\right)$ (Fig. 5). The first two irrigated fields adopted a drip irrigation system.

\section{Coordinate and GIS analysis}

In this study, the coordinates of the soils and groundwater samples were recorded by GPS with an accuracy of $\sim 5 \mathrm{~m}$. The GPS signal is corrected by a radio signal in real time. The locations of the ecosystem groundwater salinity were configured as a comma-delimited text file (in the form of groundwater, easting, and northing). The point data were overlaid on a satellite image by Arc GIS 9.3 software (ESRI, 2010) (Fig. 5). Kriging interpolation, a geostatistical method, of $\mathrm{EC}_{\mathrm{w}}$ was carried out using kriging interpolation tool of Geostatistical Analyst in ArcGIS 9.3.

\section{Statistical analysis}

Statistical analysis was carried out using the statistical package for social sciences (IBM SPSS Statistics 21 Core System, IBM Corporation, 2012). The statistical tests applied were basic statistics (maximum, minimum, mean, standard deviation, variance, standard error, median, skewness) and Spearman's correlation matrix (assuming $p<0.01$ ).

\section{Results and discussion}

\subsection{Community diagnosis of ecosystem problems}

Al-Kharj is a fragile ecosystem, highly vulnerable to environmentally induced land and water resource degradation. The ecosystem resource degradation problems in Al-Kharj are exacerbated by poor natural resource management and practices (Al-Omran et al., 2014).

The community diagnosis is considered to be a powerful investigation tool to overcome problems. The local people 


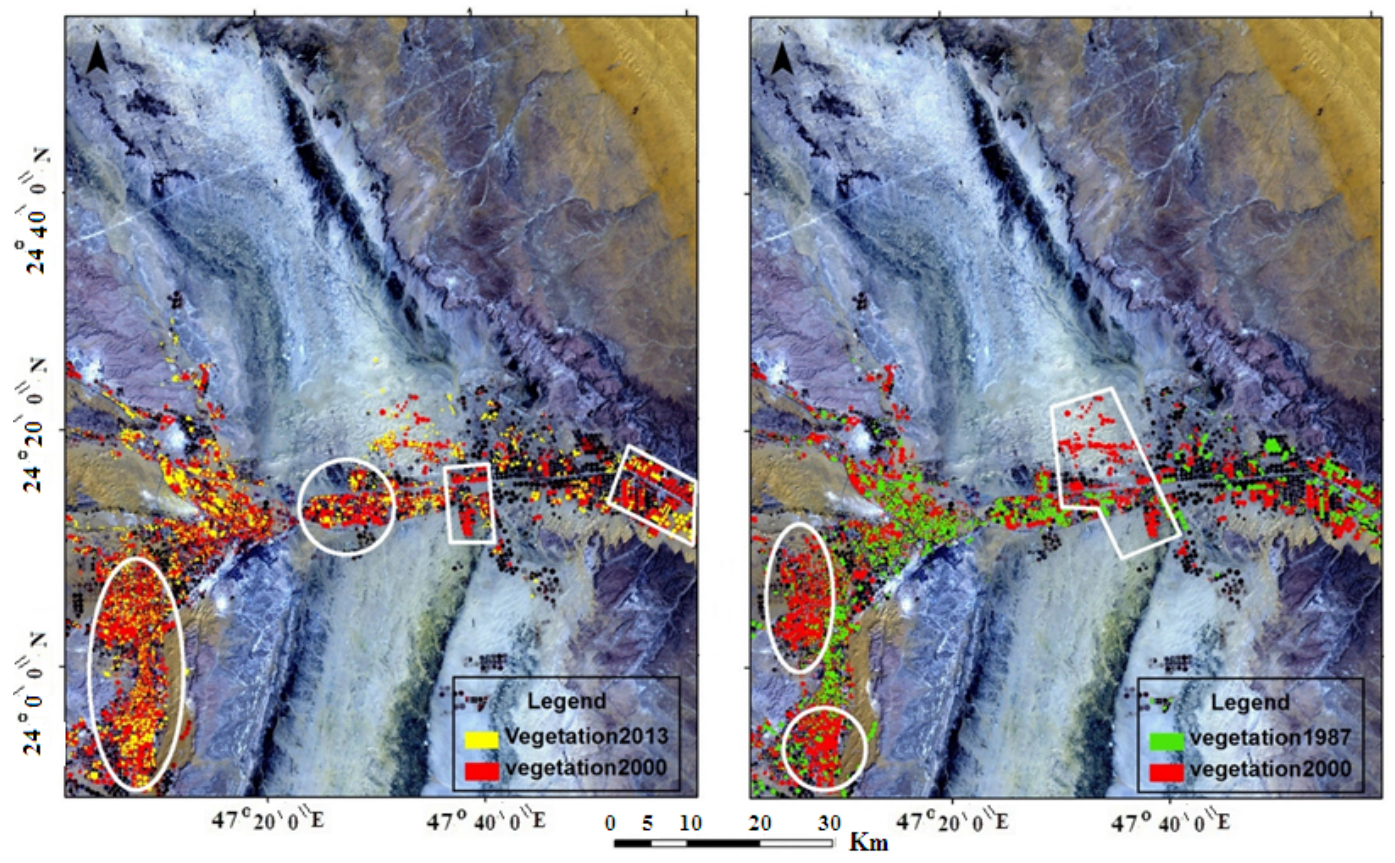

Figure 6. Change detection of vegetation cover: an increase observed between 1987 and 2000 and a decrease between 2000 and 2013.

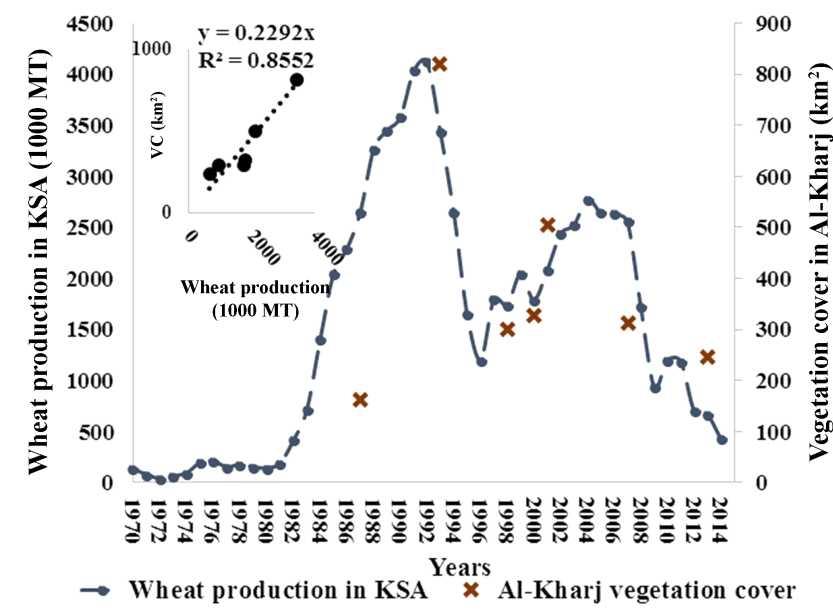

Figure 7. The changes of total vegetation cover $(\mathrm{VC})\left(\mathrm{km}^{2}\right)$ and wheat production (1000 MT) of the Al-Kharj. The three RS dates, 1993, 1998, and 2001, were for Landsat-5 from Modaihsh et al. (2015). The 2007 image was from the Landsat Thematic Mapper from Algahtani et al. (2015).

usually have a true desire to solve their ecosystem problems. The PRA techniques were used to aid describe the issues that related to the characteristics of ecosystem to issues of agricultural and environment.

As an important tool of the PRA methodology, a general townhall meeting was organized and held in the ecosystem. Most of the ecosystem residents are farmers but some of the inhabitants have other employment, e.g., merchants, civil ser-

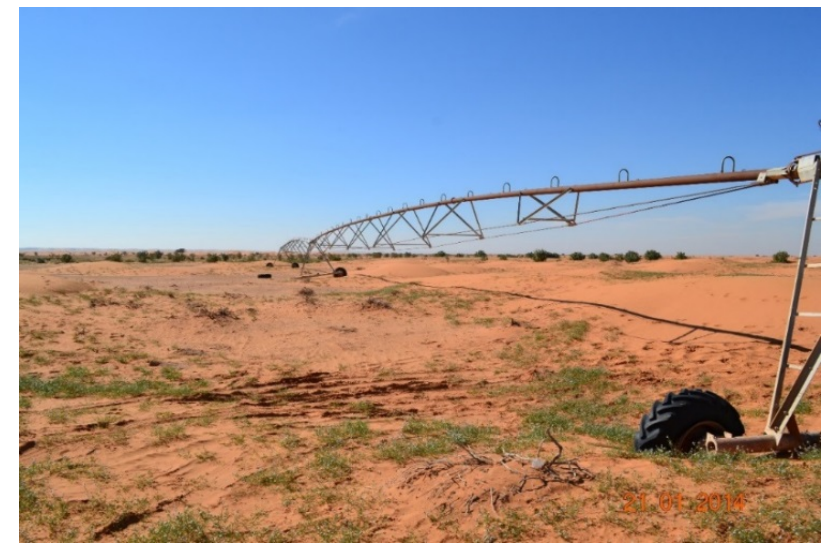

Figure 8. Sand dune encroachment in eastern part of the Al-Kharj ecosystem.

vants, and labors. The meeting was carried out by stakeholders and a large part of the ecosystem community, e.g., local government administrators, agricultural engineers and staff. The meeting was arranged to recognize how the community understands and prioritizes their land and environmental deterioration and the related issues facing them (Aly, 2007; Chambers, 1994).

Certain agricultural problems can be summarized through the community study. The PRA study found that the main agricultural problem in the studied ecosystem is the poor irrigation water quality, which is causing soil salinization problems. This problem is aggravated by several factors. 
- The number of new wells that were recently drilled for irrigation has increased dramatically, causing depletion and deterioration of groundwater quality (Al-Omran et al., 2015; Aly et al., 2016).

- Poor irrigation is practised in the Al-Kharj (excessive irrigation system). The same finding was recorded in Siwa AE, located in an Egyptian arid environment, by Aly et al. (2016). No agricultural drainage system in the Al-Kharj. Thus in some areas, the Al-Kharj could face the danger of water logging and salinization problems (Aly et al., 2016).

- Large investments in intensive cultivation, which cultivates hundreds of acres and drills tens of new wells, are causing great damage to the fragile ecosystem of the AlKharj (Algahtani et al., 2015; Aly, 2007; Sonneveld et al., 2016).

- In summer there is no agriculture activity due to high temperature (reached $50^{\circ} \mathrm{C}$ ) with the exception of protected areas (Tourenq et al., 2009).

- Some farmers use desalination plants to overcome the irrigation water salinity (Al-Omran et al., 2014).

- Biodiversity loss is due to soil salinity. This is expected since salinization is the most common land degradation processes in arid and semi-arid regions (Farifteh et al., 2006)

- Farmers in Al-Kharj usually change their soils when deteriorated (Richardson et al., 2010).

- Agricultural labor is rare and highly costly.

All the above mentioned agricultural issues and problems lead to a significant decrease in land productivity of the studied agro-ecosystem.

\subsection{Remote sensing: direction changes of vegetation cover}

The major change detected in the study area between years 1987 and 2000 was the increase of total VC in the western and southwestern parts of Al-Kharj ecosystem (Fig. 6). However, the total VC decreased between years 2000 and 2013 in the eastern and southwestern parts of Al-Kharj AE (Fig. 6). The investigation of the three satellite images concluded that the surface area in square kilometers of the total VC increased dramatically between years 1987 and 2000 by $107.4 \%$; however, it decreased by $27.5 \%$ between years 2000 and 2013 (Table 1) (Fichera et al., 2012). In an attempt to explicate the reason for the ecosystem's total VC decrease in the last decade, a relationship between total VC and wheat production has been depicted. Figure 7 shows a direct relationship between wheat production in Saudi Arabia (USDA, 2015) and total VC in Al-Kharj AE. Furthermore, it

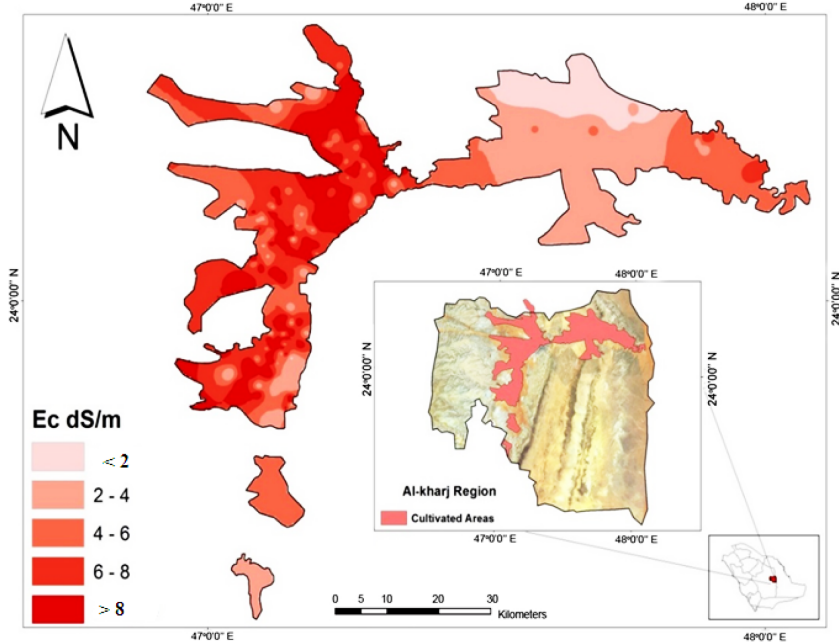

Figure 9. Interpolation of groundwater EC.

recorded evidence of progressive increase of wheat production and total VC during the period of 1984-1993 (Algahtani et al., 2015; Modaihsh et al., 2015; USDA, 2015). This was caused by the economic development that corresponds to the period of massive injection of subsidies that came with the government's policy to expand the wheat production over this period (USDA, 2015). Rationally, this has led to a steady increase in the land area used by vegetation. However, there was a nosedive during the period of 1994-1998 due to the Saudi government stopping subsidies of wheat production to save water. A slight increase of total VC was recorded between years 1998 and 2002, and a contentious decrease was seen between years 2002 and 2013. This study suggests that the decrease in the last decade of total VC was caused by land and water resources degradation (Sonneveld et al., 2016). This suggestion have been emphasized by field studies through PRA method and is in agreement with the findings of Algahtani et al. (2015).

\subsection{Soil and water resources characteristics and its effects in agro-ecosystem}

The field study and observation, the review of secondary data, and community problem diagnosis using the PRA suggest that the driving force in the change of total VC recorded by RS in recent years are the soil and water resources deterioration and salinization. The ground truth found that the deteriorated soils are either subjected to salinization or sand dune encroachment (Figs. 8, 9, and 10) (Al Omran et al., 2015; Alyemeni, 2000). In general, the sand dune in the eastern part of the studied AE is considered the main problem facing agriculture expansion; however, the groundwater salinity is considered the main problem of southwestern part (Figs. 8, 9, and 10) (Al Omran et al., 2015).

Table 2 shows that in the eastern part of the ecosystem, $83 \%$ of groundwater samples were suitable for irrigation 
Table 1. Spatiotemporal characteristics of Al-Kharj ecosystem.

\begin{tabular}{llcccr}
\hline $\begin{array}{l}\text { Reference } \\
\text { year }\end{array}$ & $\begin{array}{l}\text { Classified } \\
\text { image }\end{array}$ & \multicolumn{4}{c}{ Vegetation cover areas $\left(\mathrm{km}^{2}\right)$} \\
\cline { 3 - 6 } & & $\begin{array}{c}\text { Dense } \\
(\mathrm{NDVI}>0.5)\end{array}$ & $\begin{array}{c}\text { Moderate } \\
(\mathrm{NDVI}=0.25-0.5)\end{array}$ & $\begin{array}{c}\text { Sparse } \\
(\mathrm{NDVI}<0.25)\end{array}$ & Total \\
\hline 1987 & $\begin{array}{l}\text { Landsat4 } \\
\text { TM }\end{array}$ & 36 & 69 & 58 & 163 \\
2000 & $\begin{array}{l}\text { Landsat7 } \\
\text { ETM+ } \\
\text { Landsat8 }\end{array}$ & 8 & 156 & 174 & 338 \\
\hline
\end{tabular}

Table 2. Water and soil-deteriorated parameter (salinity) in relation to total VC area.

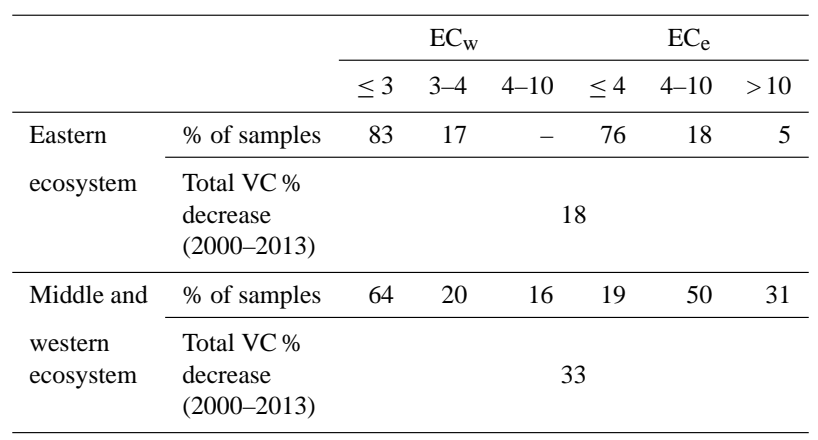

with some restriction $\left(\mathrm{EC}_{\mathrm{w}} \leq 3 \mathrm{dS} \mathrm{m}^{-1}\right)$ (Ayers and Westcot, 1985); however, the remaining their $\mathrm{EC}_{\mathrm{w}}$ ranged between 3 and $4 \mathrm{dS} \mathrm{m}^{-1}$ (Table 2). In response to irrigation water salinity, $76 \%$ of irrigated soil $\mathrm{EC}_{\mathrm{e}} \leq 4 \mathrm{dS} \mathrm{m}^{-1}, 18 \% \mathrm{EC}_{\mathrm{e}}$ ranged between 4 and $10 \mathrm{dS} \mathrm{m}^{-1}$, and $5 \%$ soil $\mathrm{EC}_{\mathrm{e}}>10 \mathrm{dS} \mathrm{m}^{-1}$. Nonetheless, the total VC area decreased by $18 \%$ between years 2000 and 2013. In the middle and western part, the ecosystem showed more vulnerable soil conditions for soil degradation. Only $64 \%$ of the groundwater can be considered suitable for irrigation $\left(\mathrm{EC}_{\mathrm{w}} \leq 3 \mathrm{dS} \mathrm{m}^{-1}\right)$. However, $20 \%$ of groundwater samples $\mathrm{EC}_{\mathrm{w}}$ ranged between 3 and $4 \mathrm{dS} \mathrm{m}^{-1}$, and $16 \%$ of the $\mathrm{EC}_{\mathrm{w}}$ ranged between 4 and $10 \mathrm{dS} \mathrm{m}^{-1}$. As a result, only $19 \%$ of the studied soil samples $\mathrm{EC}_{\mathrm{e}} \leq 4 \mathrm{dS} \mathrm{m}^{-1}, 50 \% \mathrm{EC}_{\mathrm{e}}$ between 4 and $10 \mathrm{dS} \mathrm{m}^{-1}$, and regrettably $31 \% \mathrm{EC}_{\mathrm{e}}>10 \mathrm{dS} \mathrm{m}^{-1}$. The total $\mathrm{VC}$ then decreased dramatically in this part by $33 \%$ between years 2000 and 2013. The highest soil $\mathrm{EC}_{\mathrm{e}}$ in the eastern part of the studied ecosystem was $17.6 \mathrm{dS} \mathrm{m}^{-1}$ (sample no. 1), but in the middle part of the ecosystem deteriorated sites recorded 40.6 and $47.4 \mathrm{dS} \mathrm{m}^{-1}$ for sample nos. 17 and 18 , respectively (Table 3 and Fig. 10). Moreover, the soil salinity dramatically increased in some sites of the western ecosystem, reaching $41.7 \mathrm{dS} \mathrm{m}^{-1}$ (site no. 29) (Figs. 6, 10). The groundwater in the western part of the studied ecosystem is considered highly saline since its salinity is almost more than $6 \mathrm{dS} \mathrm{m}^{-1}$ (Fig. 9). Mostly, no soil sodium hazards are antic-
Table 3. Descriptive statistics of EC $\left(\mathrm{dS} \mathrm{m}^{-1}\right)$ of soil $(n=50)$ and water samples $(n=180)$ in ecosystem areas subjected to sand dune encroachment (eastern part) or salinization (middle and western part).

\begin{tabular}{lrrrr}
\hline & \multicolumn{2}{c}{ Soil } & \multicolumn{2}{c}{ Water } \\
\cline { 2 - 5 } & Eastern part & $\begin{array}{r}\text { Middle and } \\
\text { western part }\end{array}$ & Eastern part & $\begin{array}{r}\text { Middle and } \\
\text { western part }\end{array}$ \\
\hline Max. & 17.63 & 47.35 & 3.82 & 10.15 \\
Min. & 2.50 & 2.34 & 1.31 & 1.83 \\
Mean & 3.05 & 12.11 & 2.50 & 3.22 \\
Med. & 2.66 & 7.12 & 2.54 & 2.73 \\
SD $^{2}$ & 7.51 & 12.01 & 0.71 & 1.42 \\
\hline
\end{tabular}

${ }^{1}$ Med. is the median; ${ }^{2} \mathrm{SD}$ is the standard deviation.

ipated by using this type of groundwater in irrigation. The sodium adsorption ratio of studied water samples were less than 10 with an average of 3.74 (Table 4) (Richards, 1954). In general, $34.8 \%$ of the arable land in the studied $\mathrm{AE}$ is considered saline $\left(\mathrm{EC}_{\mathrm{e}}>4 \mathrm{dS} \mathrm{m}^{-1}\right), 34.8 \%$ is severely saline $\left(\mathrm{EC}_{\mathrm{e}}>10 \mathrm{dS} \mathrm{m}^{-1}\right)$, and the remaining $(30.4 \%)$ can be considered non-saline $\left(\mathrm{EC}_{\mathrm{e}}<4 \mathrm{dS} \mathrm{m}^{-1}\right)$. The $\mathrm{EC}_{\mathrm{e}}$ of Al-Kharj cultivated soils ranged between 1 and $47.4 \mathrm{dS} \mathrm{m}^{-1}$ for nondeteriorated and deteriorated sites, respectively; however, the uncultivated soil $\mathrm{EC}_{\mathrm{e}}$ reached $140 \mathrm{dS} \mathrm{m}^{-1}$ in western $\mathrm{AE}$.

\subsection{Total VC degradation and land and water resource salinity}

In order to prove that the land and water resource salinity of past 10 years are the main cause of total $\mathrm{VC}$ decrease in the ecosystem, the changes of total VC have been linked to water and soil salinity levels at three different fields (Figs. 5, 11). The soil parameters (soil moisture, EC, and temperature) were recorded at investigated fields by sensors. The average values of the soil parameters of four date palms at depth $(0-30 \mathrm{~cm})$ for each field were presented in Fig. 11. The sensors in abandoned field did not work properly due to the low soil water content $\left(\sim 0.01 \mathrm{~m}^{3} \mathrm{~m}^{-3}\right)$ where the precipitation is negligible (Gao et al., 2014; Saha et al., 2015). The re- 
Table 4. Statistical analysis of groundwater chemical composition of Al-Kharj $(n=180)$.

\begin{tabular}{|c|c|c|c|c|c|c|c|c|c|c|c|}
\hline & PH & $\begin{array}{r}\mathrm{EC} \\
\mathrm{dS} \mathrm{m}^{-1}\end{array}$ & $\mathrm{Ca}^{2+}$ & $\mathrm{Mg}^{2+}$ & $\mathrm{Na}^{+}$ & $\mathrm{K}_{\mathrm{me}}^{+}$ & $\begin{array}{c}\mathrm{Cl}^{-} \\
\mathrm{L}^{-1}\end{array}$ & $\mathrm{HCO}_{3}^{-}$ & $\mathrm{CO}_{3}^{-2}$ & $\mathrm{SO}_{4}^{-2}$ & $\begin{array}{r}\text { Sodium } \\
\text { adsorption } \\
\text { ratio }\end{array}$ \\
\hline Max. & 8.60 & 10.15 & 36.75 & 29.85 & 43.40 & 0.72 & 58.17 & 18.83 & 4.33 & 43.19 & 9.14 \\
\hline Min. & 6.78 & 1.05 & 3.45 & 0.79 & 2.24 & 0.05 & 3.13 & 0.87 & 0.00 & 3.22 & 1.08 \\
\hline Mean & 7.72 & 3.00 & 10.79 & 7.78 & 11.28 & 0.25 & 10.86 & 3.99 & 0.13 & 15.03 & 3.74 \\
\hline $\mathrm{SD}$ & 0.44 & 1.29 & 5.09 & 3.93 & 5.96 & 0.10 & 7.32 & 1.49 & 0.37 & 7.05 & 1.47 \\
\hline Vari. $^{1}$ & 0.66 & 1.13 & 2.26 & 1.98 & 2.44 & 0.31 & 2.71 & 1.22 & 0.61 & 2.66 & 1.21 \\
\hline St. error ${ }^{2}$ & 0.18 & 0.23 & 0.33 & 0.31 & 0.34 & 0.12 & 0.36 & 0.24 & 0.17 & 0.36 & 0.24 \\
\hline Med. & 7.72 & 2.64 & 9.60 & 6.69 & 10.21 & 0.23 & 9.50 & 3.83 & 0.00 & 12.83 & 3.51 \\
\hline Skew. ${ }^{3}$ & -0.15 & 2.47 & 1.39 & 2.16 & 2.53 & 1.66 & 3.85 & 5.96 & 8.20 & 1.18 & 1.12 \\
\hline
\end{tabular}

${ }^{1}$ Vari. is the variance; ${ }^{2}$ st. error is the standard error; ${ }^{3}$ skew. is the skewness.

sults indicated that the irrigation with low water salinity in the first field did not lead to high soil salinity values (average soil $\mathrm{EC}=1.25 \mathrm{dS} \mathrm{m}^{-1}$ ) (Fig. 11). The leaching process led to the soil salinity to get lower with adding irrigation. However, the irrigation with saline water in the second field led to soil quality deterioration due to salinity (average soil salinity was equal to $6.7 \mathrm{dS} \mathrm{m}^{-1}$ ) (Fig. 11). The soil in the abandoned field is suffering from severe salinity (averaged $39.2 \mathrm{dS} \mathrm{m}^{-1}$ ) due to lack of irrigation and the low precipitation. Subsequently, soluble salts have accumulated in the top soil layer, thus negatively impacting total VC water uptake and growth due to low tolerance of the total VC to very high salinity. These are expected results as salinization and alkalinization are the most common land degradation processes in arid and semi-arid regions (Farifteh et al., 2006). Since the temperature of $\mathrm{Al} \mathrm{Kharj}$ reaches $45^{\circ} \mathrm{C}$ in July, the soil temperature was also investigated in this study. Figure 11 clearly demonstrates that the summer irrigation led to a dramatic decrease of soil temperature (up to $5^{\circ} \mathrm{C}$ ). During the irrigation, the air is replaced with water leading to the decrease in soil temperature. In contrast, following the irrigation, the water drains and air fills up the soil pores and the soil temperature gets higher (Fig. 11) (USAD, 2002). Comparing the three sites of total VC, it is clear that the high salinity of the land caused by high salinity of groundwater resources had a negative impact on vegetation survival, especially in the absence of salt leaching by rainfall or fresh irrigation water. In addition, the sand dune encroachment represents another cause of the total $\mathrm{VC}$ decrease in the eastern part of the study sites (Fig. 8). The farmers of Al-Kharj should be informed about the water quality of their wells and should be given advice by the extension services about the type of suitable crops and management that would safeguard the Al-Kharj ecosystem. The government should take action to solve the problem of sand dune encroachment in the eastern part of the ecosystem and help farmers select salinity-tolerant crops that can survive such conditions. Sand dune fixation is generally used to stop the dunes encroachment. Two methods

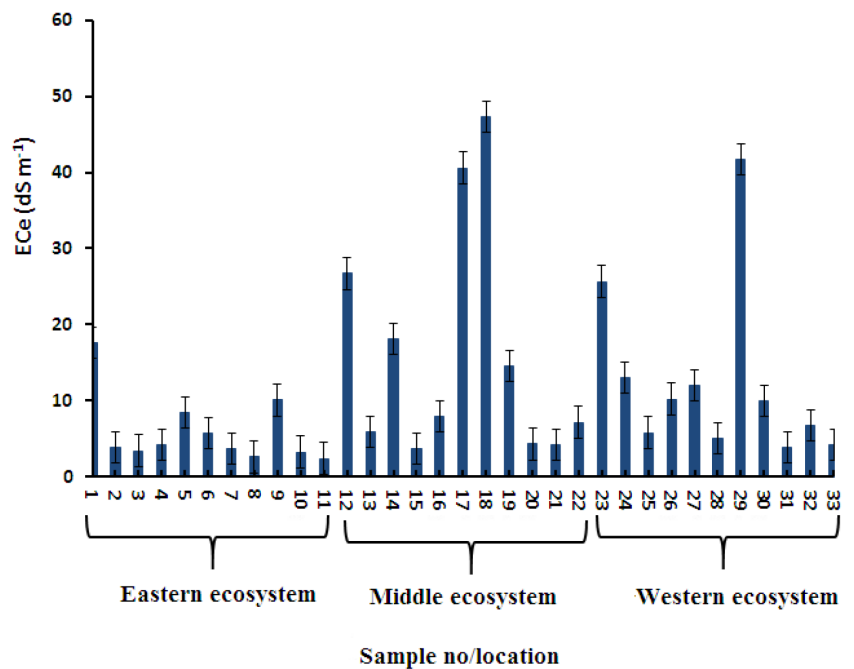

Figure 10. Salinity of selected soil samples $(n=33)$.

are usually used: biological (i.e., planting trees, shrubs, and grass species) and mechanical (i.e., wooden sand fences and footpaths). Shelter-belt systems and afforestation, biological methods, using Atriplex spp., Acacia spp., and Casuarina spp. were found to be efficient in stabilizing dunes in arid environments of Egypt, Senegal, and India (Draz et al., 1992; Kaul, 1985). In fact, the importance of the sand dunes fixation by afforestation is not only sand dune fixation but also can conserve arid ecosystem balance and produce fuel and animal feed (Draz et al., 1992; Kaul, 1985).

Saline waters have been successfully used for a long irrigation time in the USA, Tunisia, and Egypt. The crops irrigated with this water are cotton, sugar beet, alfalfa, date palm, sorghum, barley, alfalfa, rye grass, and artichoke (Rhoades et al., 1992). In Texas, USA, the saline groundwater (TDS $=2500$ to $6000 \mathrm{mg} \mathrm{L}^{-1}$ ) has been used for 3 decades (Rhoades et al., 1992). The suitability of saline groundwater for irrigation should be assessed for specific 


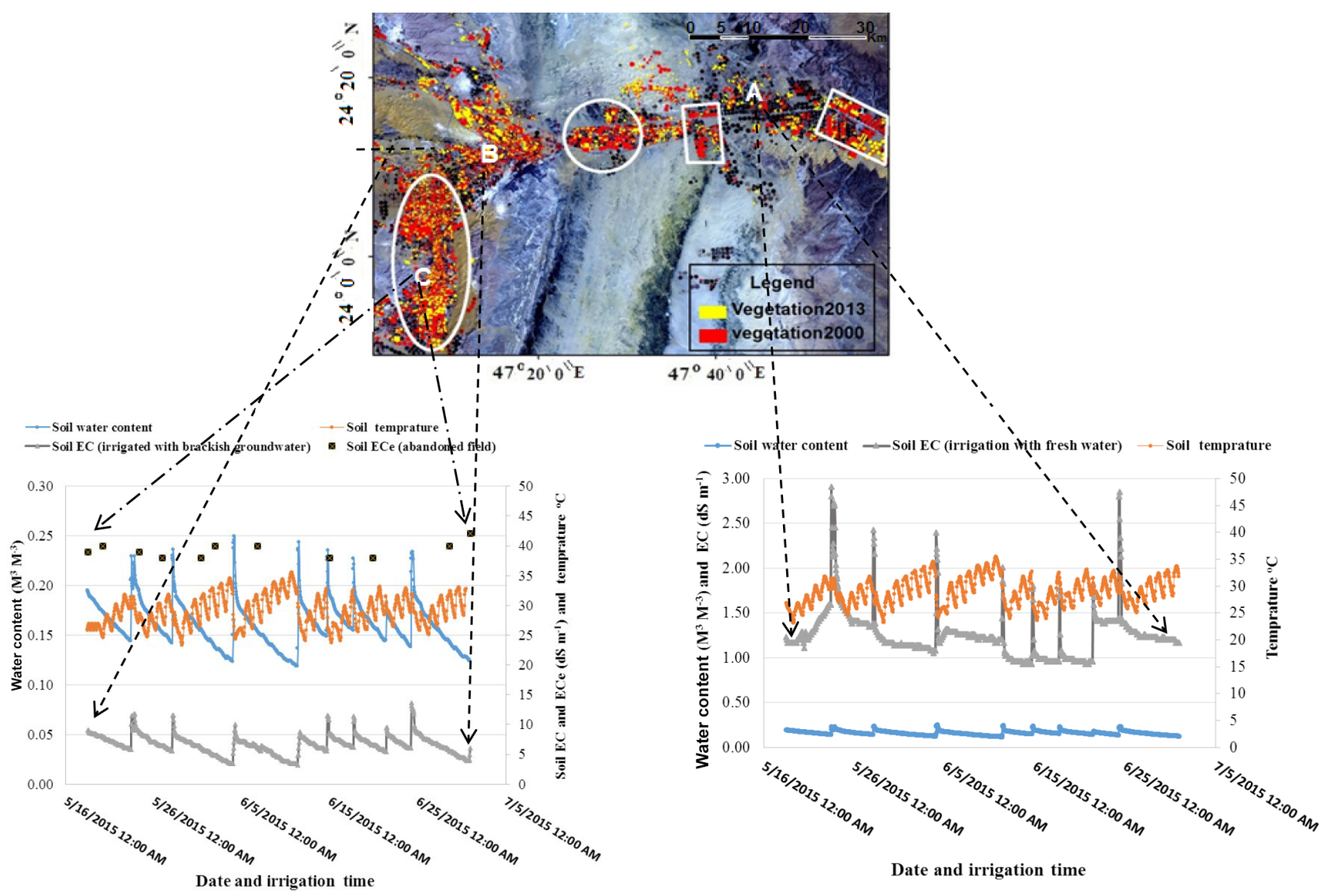

Figure 11. The changes of VC between years 2000 and 2013 linked to soil salinity, water content, and temperature at different fields in Al Kharj ecosystem: (a) field with no change of $\mathrm{VC}$ that used fresh water for irrigation $\left(\mathrm{EC}_{\mathrm{w}}=1.1 \mathrm{dS} \mathrm{m}^{-1}\right)$; (b) deteriorated field that used saline brackish water for irrigation $\left(\mathrm{EC}_{\mathrm{W}}=6.5 \mathrm{dS} \mathrm{m}^{-1}\right)$; (c) abandoned field with no irrigation $\left(\mathrm{EC}_{\mathrm{W}}=10.2 \mathrm{dS} \mathrm{m}^{-1}\right)$.

conditions including crops type, soil characteristics, irrigation methods, cultural practices, and climatic conditions (Minhas, 1996). Many rational management options of saline irrigation water are currently in use, including cyclic strategy, which involves using non-saline water and saline water in a repeating sequence, blending strategy, which involves blending (dilution process) fresh with saline water, rotation strategy, which means irrigation with low-salinity water for salt sensitive crops in a rotation with saline water for salt-tolerant crops (Rhoades et al., 1992), planting salt tolerant crop varieties or genotypes/cultivars, i.e., amaranth and quinoa, which can survive under harsh conditions (Fghire et al., 2015; Pulvento, et al., 2015), and finally the use of computer model for assessing water suitability for crops production (Aly et al., 2015b).

\section{Conclusions}

A comprehensive analysis of Al-Kharj, Saudi Arabia, agroecosystem components (physical resources and community) was conducted in this study. The field study and community- based diagnosis in addition to the use of satellite images to detect agriculture land-use changes over the 26 years revealed that the groundwater and agricultural lands have been seriously degraded due to salinization. The major ecosystem change detected by RS was the increase of total VC surface area between years 1987 and 2000 by $107.4 \%$ and the decrease by $27.5 \%$ between years 2000 and 2013. Between years 1984 and 1998, a direct relationship between wheat production in Saudi Arabia and total VC changes in studied AE is recorded. The Saudi government subsidies to wheat production govern the total VC changes in this period. However, in the following years, the degradation of land and water resources induced the total VC changes. This study found that the sand dune encroachment in the eastern part of the $\mathrm{AE}$ is the main problem facing agriculture expansion, whereas the land and groundwater salinity is considered the main problem in the middle and southwestern ecosystem. In the eastern ecosystem, $83 \%$ of the studied groundwater samples were suitable for irrigation with some restrictions $\left(\mathrm{EC}_{\mathrm{w}} \leq 3 \mathrm{dS} \mathrm{m}^{-1}\right)$ and $76 \%$ of irrigated soil $\mathrm{EC}_{\mathrm{e}} \leq 4 \mathrm{dS} \mathrm{m}^{-1}$. However, in the middle and western part, $64 \%$ of the groundwater can be considered suitable for 
irrigation $\left(\mathrm{EC}_{\mathrm{w}} \leq 3 \mathrm{dS} \mathrm{m}^{-1}\right)$, and only $19 \%$ of the studied soil samples had $\mathrm{EC}_{\mathrm{e}} \leq 4 \mathrm{dS} \mathrm{m}{ }^{-1}$. The farmers of Al-Kharj should be informed about the water quality of their wells and should be given advice by the extension services about the type of suitable crops and management that would safeguard the Al-Kharj ecosystem.

\section{List of abbreviations}

EM is ecosystem management; RS is remote sensing; GIS is geographic information systems; GPS is global positioning system, LC is land cover; LU is land use; VC is vegetation cover; AE is agro-ecosystem; PRA is participatory rural appraisal; $\mathrm{EC}_{\mathrm{w}}$ is electrical conductivity measured on groundwater samples; $\mathrm{EC}_{\mathrm{e}}$ is electrical conductivity measured on soil samples using saturated paste extracts.

\section{The Supplement related to this article is available online at doi:10.5194/se-7-713-2016-supplement.}

Acknowledgements. This project was supported by NSTIP strategic technologies program number 12-ENV2581-02 in the Kingdom of Saudi Arabia.

Edited by: A. Cerdà

\section{References}

Algahtani, O. S., Salama, A. S., Iliyasu, A. M., Selim, B. A., and Kheder, K.: Monitoring urban and land use changes in Al-Kharj Saudi Arabia using remote sensing techniques. Progress in systems engineering: Proceedings of the twenty-third international conference on systems engineering, Advances in Intelligent Systems and Computing 1089, Springer International Publishing Switzerland 2015, 75, 515-523, 2015.

Al-Harbi, M. A.: Effect of Cultivation Periods on Pedological Characteristics of some Soils in Harrad and Al-Kharj, M. Sc. Thesis, Soil Science Department, College of Agriculture, King Saud University, Saudi Arabia, 2005.

Almeida, C. M., Monteiro, A. M. V., Mara, G., Soares-Filho, B. S., Cerquera, G. C., Pennachin, C. S. L., and Batty, M.: GIS and remote sensing as tools for the simulation of urban land-use change, Int. J. Remote Sens., 26, 759-774, 2005.

Al-Omran, A. M., Louki, I. I., Aly, A. A., and Nadeem, M. E.: Impact of Deficit Irrigation on Soil Salinity and Cucumber Yield under greenhouse condition in arid environment, J. Agr. Sci. Technol., 15, 1247-1259, 2013.

Al-Omran, A. M., Aly, A., and Sallam, A.: A Holistic Ecosystem Approach for the Sustainable Development of Fragile Agroecosystems: A case study of the Al-Kharj Ecosystem, Saudi Arabia. National Science, Technology and Innovation Plan, Kingdom of Saudi Arabia, for financial support of project 12ENV2581-02, 2014.
Al-Omran, A. M., Aly, A. A., Al-Wabel, I. M., Sallam, A. S., and Al-Shayaa, M. S.: Hydrochemical Characterization of Groundwater under Agricultural Land in Arid Environment: a Case Study of Al-Kharj, Saudi Arabia, Arab. J. Geosci., 9, 9-15, 2015.

Aly, A. A.: A Holistic Ecosystem Approach for Sustainable Management of Land and Water Resources in Siwa Oasis. PhD Thesis, Faculty of Agriculture, Alexandria University, Egypt, 2007.

Aly, A. A., Al-Omran, A. M., and Alharby, M. M.: The water quality index and hydrochemical characterization of groundwater resources in Hafar Albatin, Saudi Arabia, Arab. J. Geosci., 8, 4-5, $2015 \mathrm{a}$.

Aly, A. A., Al-Omran, A. M., and Khasha, A.: Water management for cucumber: Greenhouse experiment in Saudi Arabia and modeling study using SALTMED model, J. Soil Water Conserv., 70, $1-11,2015 b$.

Aly, A. A., Kishk, F. M., Gaber, H. M., and Al-Omran, A. M.: Longterm detection and hydrochemistry of groundwater resources in Egypt: Case study of Siwa Oasis, J. Saudi Soc. Agr. Sci., 15, 67-74, 2016.

Alyemeni, M. N.: Ecological Studies on Sand dunes Vegetation in AI-Kharj region, Saudi Arabia, Saudi J. Biol. Sci., 7, 64-87, 2000.

Ayers, A. S. and Westcot, D. W.: Water Quality for Agriculture, Irrigation and Drainage Paper 29 (Rev.1), FAO, Rome, Italy, 1985.

Berendse, F., van Ruijven, J., Jongejans, E., and Keesstra, S. D.: Loss of plant species diversity reduces soil erosion resistance of embankments that are crucial for the safety of human societies in low-lying areas, Ecosystems, 18, 881-888, 2015.

Bochet, E.: The fate of seeds in the soil: a review of the influence of overland flow on seed removal and its consequences for the vegetation of arid and semiarid patchy ecosystems, Soil, 1, 131146, 2015.

Brevik, E. C., Cerdà, A., Mataix-Solera, J., Pereg, L., Quinton, J. N., Six, J., and Van Oost, K.: The interdisciplinary nature of Soil, Soil, 1, 117-129, 2015.

Brodt, S., Six, J., Feenstra, G., Ingels, C., and Campbell, D.: Sustainable Agriculture, Nature Education Knowledge, 2, available at: http://www.nature.com/scitable/knowledge/ library/sustainable-agriculture-23562787 (last access: 11 March 2015), 2011.

Cerdà, A.: Parent material and vegetation affect soil erosion in eastern Spain, Soil Sci. Soc. Am. J., 63, 362-368, 1999.

Cerdà, A. and Doerr, S. H.: Influence of vegetation recovery on soil hydrology and erodibility following fire: An 11-year investigation, Int. J. Wildland Fire, 14, 423-437, 2005.

Chambers, R.: Participatory Rural Appraisal (PRA): Analysis of Experience, World Dev., 22, 1253-1268, 1994.

Chowdary, V. M., Paul, S., Kumar, T., Sudhakar, S., and Adiga, S.: Remote sensing and GIS approach for watershed monitoring and Asian Conference on Remote Sensing, 5-9 November 2001, Singapore, 2, 802-807, 2001.

Croft, H., Kuhn, N. J., and Anderson, K.: On the use of remote sensing techniques for monitoring spatio-temporal soil organic carbon dynamics in agricultural systems, Catena, 94, 64-74, 2012.

Dagci, M. and Kusek, G.: Monitoring microcatchment by using satellite imagery: Kiziloz sample, in: Integration of information for environmental security, edited by: Coskun, H. G., Cigizoglu, H. K., and Makktav, D., Springer, 175-189, 2008. 
Debolini, M., Schoorl, J. M., Temme, A., Galli, M., and Bonari, E.: Changes in Agricultural Land Use Affecting Future Soil Redistribution Patterns: A Case Study in Southern Tuscany (Italy), Land Degrad. Dev., 26, 574-586, 2015.

Desprats, J. F., Al-Omran, A. M., and Desmartis, B.: Harrats project - Evaluation of water requirement for irrigated agriculture with remote sensing, BRGM/RP-63531-FR, p. 45, 2014.

Draz, M. Y., Ahmed, A. M., and Afify, M. Y.: Studies on sand encroachment in Siwa Oasis, Western desert, Egypt, II - Feasibility of sand dune fixation measures, J. Eng. and Appl. Sci., 39, 723$725,1992$.

Ehlers, M., Edwards, G., and Bedard, Y.: Integration of remote sensing with geographic information system: A necessary evolution, Photogramm. Eng. Rem. S., 55, 1619-1627, 1989.

EL-Bana, T. A.: Agro-ecological assessment of land and water resources Norther Nile delta: A case study in kafr EL-Sheikh governorate: M.Sc. Thesis, Fac. Of Agric., Alex. Univ., Egypt, 2003.

ESRI: Arc View version 10 user manual, Redlands, CA, USA, 2010.

Farifteh, J., Farshad, A., and George, R. J.: Assessing salt-affected soils using remote sensing, solute modelling, and geophysics, Geoderma, 130, 191-206, 2006.

Fghire, R., Wahb, S., Anaya, F., Ali, O., Benlhabib, O., and Ragab, R.: Response of quinoa to different water management strategies: field experiments and saltmed model application results, Irrig. Drain., 64, 29-40, 2015.

Fichera, C. R., Modica, G., and Pollino, M.: Land Cover classification and change-detection analysis using multi-temporal remote sensed imagery and landscape metrics, Eur. J. Remote Sens., 45, $1-18,2012$.

Gao, J.: Integration of GPS with Remote Sensing and GIs: Reality and Prospect, Photogramm. Eng. Rem. S., 68, 447-453, 2002.

Gao, X., Wu, P., Zhao, X., Wang, J., and Shi, Y.: Effects of land use on soil moisture variations in a semi-arid catchment: Implications for land and agricultural water management, Land Degrad. Dev., 25, 163-172, 2014.

GeoMart: Understanding Color Infrared (CIR) Aerial Photography, available at: http://www.geomart.com/products/aerial/cir. htm, last access: 28 June 2011.

Gong, Z., Kawamura1, K., Ishikawa, N., Goto, M., Wulan, T., Alateng, D., Yin, T., and Ito, Y.: MODIS normalized difference vegetation index (NDVI) and vegetation phenology dynamics in the Inner Mongolia grassland, Solid Earth, 6, 1185-1194, doi:10.5194/se-6-1185-2015, 2015.

Hagras, M. A., Elmoustafa, A. M., and Ahmed, K.: Flood plain mitigation in arid regions case study: South of Al-Kharj city, Saudi Arabia, IJRRAS, 16, 147-156, 2013.

Hinto, J. C.: GIs and remote sensing integration for environmental applications, Int. J. Geogr. Inf. Syst., 10, 877-890, 1996.

Jenny, H.: The soil resource origin and behavior, Springer Verlag, New York, 1962.

Kaul, R. N.: A forestation of dune area, in: Sand dune stabilization, shelterbelts and afforestation in the dry zones, FAO Conservation Gudie, 10, 75-85, 1985.

Keesstra, S. D., Geissen, V., van Schaik, L., Mosse, K., and Piiranen, S.: Soil as a filter for groundwater quality, Curr. Opin. Environ. Sust., 4, 507-516, 2012.

Klute, A.: Methods of soil analysis, Part 1. 2nd Edn., Agron Monor. 9. ASA and SSSA, Madison, WI, 1986.
Leh, M., Bajwa, S., and Chaubey, I.: Impact of land use change on erosion risk: and integrated remote sensing geopraphic information system and modeling methodology, Land Degrad. Dev., 24, 409-421, 2013.

Lucas, R., Rowlands, A., Brown, A., Keyworth, S., and Bunting, P.: Rule-based classification of multi-temporal satellite imagery for habitat and agricultural land cover mapping, ISPRS J. P. Remote Sens., 62, 165-185, 2007.

Maltby, E.: Ecosystem approach: From principle to practice Ecosystem Service and Sustainable Watershed Management in North China, International Conference, Beijing, P.R. China, 205-224, 2000.

Matiti, S. K.: Handbook of methods in environmental studies: water and wastewater analysis ABD Publishers, Jaipur (India), 2004.

McLaren, S. J., Al-Juaidi, F., Bateman, M. D., and Millington, A. C.: First evidence for episodic flooding events in the arid interior of central Saudi Arabia over the last $60 \mathrm{ka}$, J. Quaternary Sci., 24, 198-207, 2008.

Mikkelson, B.: Methods for development work and research: A guide for practitioners, New Delhi/Thousand oaks/London, Saga Publications, 1994.

Minhas, P. S.: Saline water management for irrigation in India, Agr. Water Manag., 30, 1-24, 1996.

Modaihsh, A. S., Mahjoub, M. O., Sallam, A. S., and Ghoneim, A. M.: Evaluation of soil degradation in Al-Kharj center, Saudi Arabia using remote sensing, Int. J. Remote Sens. Geosci., 4, $2-$ 7, 2015.

Mohawesh, Y., Taimeh, A., and Ziadat, F.: Effects of land use changes and soil conservation intervention on soil properties as indicators for land degradation under a Mediterranean climate, Solid Earth, 6, 857-868, doi:10.5194/se-6-857-2015, 2015.

Muñoz-Rojas, M., Jordán, A., Zavala, L. M., De la Rosa, D., AbdElmabod, S. K., and Anaya-Romero, M.: Impact of Land Use and Land Cover Changes on Organic Carbon Stocks in Mediterranean Soils (1956-2007), Land Degrad. Dev., 26, 168-179, 2015.

Mushove, P. and Vogel, C.: Heads or tails? Stakeholder analysis as a tool for conservation area management, Global Environ. Chang., 15, 184-198, 2005.

Pulvento, C., Lavini, A., Riccardi, M., Andria, R. D., and Ragab, R.: Assessing Amaranth Adaptability in a Mediterranean Area of South Italy under Different Climatic Scenarios, Irrig. Drain., 64, 50-58, 2015.

Rawat, J. S., Biswas, V., and Kumar, M.: Changes in land use/cover using geospatial techniques: A case study of Ramnagar town area, district Nainital, Uttarakhand, India, Egypt, J. R. S. Space Sci., 16, 111-117, 2013.

Reed, M. S., Graves, A., Dandy, N., Posthumus, H., Hubacek, K., Morris, J., Prell, C., Quinn, C. H., and Stinger, L. C.: Who's in and why? A typology of stakeholder analysis methods for natural resource management, J. Environ. Manag., 90, 1933-1949, 2009.

Rhoades, D., Kandiah, A., and Mashali, A. M.: The use of saline waters for crop production, Irrig. Drain., 48, 11-98, 1992.

Richards, L. A. (Ed.): Diagnosis and improvement of saline and alkali soils, USDA Hand book, 60, 4-80, 1954.

Richardson, P. J., Lundholm J. T., and Larson D. W.: Natural analogues of degraded ecosystems enhance conservation and reconstruction in extreme environments, Ecol. Appl., 20, 728-740, 2010. 
Saha, D. and Kukal, S. S.: Soil structural stability and water retention characteristics under different land uses of degraded lower himalayas of North-West India, Land Degrad. Dev., 26, 263-271, 2015.

Seelan, K. S., Laguette, S., Casady, G. M., and Seielstad, G. A.: Remote sensing applications for precision agriculture: A learning community approach, Remote Sens. Environ., 88, 157-169, 2003.

Setiawan, Y. and Yoshino, K.: Change detection inland-use and land-cover dynamics at a regional scale from modis time-series imagery, ISPRS Annals of the Photogrammetry, Remote Sensing and Spatial Information Sciences, Volume I-7, 2012 XXII ISPRS Congress, 25 August-1 September 2012, Melbourne, Australia, 2012.

Shepherd, G. (Ed.).: The Ecosystem Approach: Learning from Experience. International Union for Conservation of Nature and Natural Resources, Gland, Switzerland, 2008.

Singh, B. G.: Detection of land use and land cover change with Remote Sensing and GIS: A case study of Punjab Siwaliks, Int. J. Geom. Geosci., 4, 296-304, 2013.

Sonneveld, B. G., Keyzer, M. A., and Ndiaye, D.: Quantifying the impact of land degradation on crop production: the case of Senegal, Solid Earth, 7, 93-103, doi:10.5194/se-7-93-2016, 2016.

Suliman, A. S.: Change detection from satellite images in Nile Delta Coastal, Egypt, Alexandria Journal of Agriculture Research, 46, 177-188, 2001.

Swallow, B. M., Kallesoe, M. F., Iftikhar, U. A., Van Noordwijk, M., Bracer, C., Scherr, S. J., Raju, K. V., Poats, S. V., Kumar Duraiappah, A., Ochieng, B. O., Mallee, H., and Rumley, R.: Compensation and rewards for environmental services in the developing world: framing pan-tropical analysis and comparison, Ecol. Soc., 14, 26-30, 2009.

Tourenq, C., Khassim, A., Sawaf, M., Shuriqi, M. K., Smart, E., Ziokowski, M., Brook, M., Wan, R. S., and Perry, L.: Characterisation of the Wadi Wurayah Catchment Basin, the First Mountain Protected Area in the United Arab Emirates, Int. J. Ecol. Environ. Sci., 35, 289-311, 2009.
Trabaquini, K., Formaggio, A. R., and Galvão, L. S.: Changes in physical properties of soils with land use time in the Brazilian savanna environment, Land Degrad. Dev., 26, 397-408, 2015.

United States Department of Agriculture (USDA): Saudi Arabia Wheat Production by Year, available at: http: //www.indexmundi.com/agriculture/?country=sa\&commodity= wheat\&graph=production, last access: April 2016.

USDA: The temperature regime for selected soils in the United States. Soil survey investigations, report no. 48, National soil survey center, Lincoln, Nebraska, 2002.

Vrieling, A.: Satellite remote sensing for water erosion assessment: A review, Catena, 65, 2-18, 2006.

Xie, Y., Sha, Z., and Yu, M.: Remote sensing imagery in vegetation mapping: a review, J. Plant Ecol., 1, 9-23, 2008.

Yang, X., Damen, M. C. J., and van Zuidam, R. A.: Satellite remote sensing and GIS for the analysis of channel migration changes in the active Yellow River Delta, China. J. Aquat. Geol., 1, 146157, 1999.

Yu, Y. and Jia, Z. Q.: Changes in soil organic carbon and nitrogen capacities of Salix cheilophila Schneid along a revegetation chronosequence in semi-arid degraded sandy land of the Gonghe Basin, Tibet Plateau, Solid Earth, 5, 1045-1054, doi:10.5194/se5-1045-2014, 2014.

Yuan, F., Sawaya, K. E., Loeffelholz, B. C., and Bauer, M. E.: Land cover classification and change analysis of the Twin Cities (Minnesota) Metropolitan Area by multitemporal Landsat remote sensing, Remote Sens. Environ., 98, 317-328, 2005

Zucca, C., Wu, W., Dessena, L., and Mulas, M.: Assessing the effectiveness of land restoration intervention in dry lands by multitemporal remote sensing - A case study in Ouled Dlim (Marrakesh, Morocco), Land Degrad. Dev., 26, 80-91, 2015. 